\title{
Including the Excluded LGBT + Minority in Rio de Janeiro: How Long Is It Going to Last?
}

\author{
Neide Lucia De Oliveira Almeida ${ }^{*}$, Emmanuel Paiva De Andrade ${ }^{2}$, Edna \\ Ribeiro Alves ${ }^{1}$
}

1. Fluminense Federal University-UFF

2. Department of Production Engineering Knowledge, People and Innovation Research Group (GECOPI), Fluminense Federal University-UFF

*Corresponding Author: Neide Lucia De Oliveira Almeida Abstract: The present work, which is a qualitative research, aims to present a case study on what has
been done by the municipal public power through the Special Coordination for Sexual Diversity (CEDS)
in terms of guaranteeing human rights and the inclusion of the LGBT+ population of the city of Rio de
Janeiro, capital of the State of Rio de Janeiro, in the South-eastern region of Brazil, from 2011 to 2016 .
The objective is to identify the public policies and actions adopted and the impact perceived in the
improvement of working conditions and quality of life for this population. Among the possible
methodological variations, this article develops a case study on programs implemented by the
Coordination for Sexual Diversity (CEDS) of the City Hall of the city of Rio de Janeiro. Seeking to meet
the requirement of having multiple sources of evidence required by the case studies, data were collected
from documentary evidence obtained at electronic websites of the city of Rio and printed articles
pertinent to published achievements, as well as an in-depth interview with the coordinator responsible
for the implementation and management of the programs. Steps were taken towards valuing and
including LGBT+ minorities through the creation of CEDS/ Rio, which became responsible for the
defense of LGBT+ Civil Rights through the care, reception and referral of complaints made by citizens
in vulnerable conditions, which contributed to the per- ception of belongingness and solidarity of the
State towards its citizens. Including the excluded LGBT+ minority is an example that should be
followed in order inequalities are reduced in developed and underdeveloped countries.
Keywords: Reducing Discrimination, Human Rights, and Inclusion of Minority, LGBT+, Gay Friendly
City, and Rio de Janeiro.

\section{Introduction}

In recent decades, organizational leaders have been recognizing that the commitment to equity and inclusion involves not only issues of race, gender and people with disabilities, but also engaging with the needs of LGBT+ workers, and developing and implementing systems and practices to tackle with issues related to this diversity that is as contemporary as it is real, in work environments [1-2-3].

Leaders who are prepared, enlightened, and capable of encouraging the self-development of their team and who have the ability to communicate are able to create a conducive work environment for their employees, making it an ideal place to exercise work activities [4]. Once the worker has his macro necessities met, he will be able to offer his maximum effort and dedication to the organization, allowing, in return, the attraction and retention of talents that integrate the intellectual capital of these same organizations [5-6]. Thus, the best practices focused on the issues of inclusion of diversity are those that focus on creating positive and respectful relationships among different stakeholders, reducing discrimination and generating effective financial returns to organizations [3]. The friendship established in the work environment is a resource for mentoring, career management and the development of LGBT+ identities in organizational culture [7].

It is concluded that the sense of belongingness in a 'gay-friendly' work environment through formal signals of a policy of equal opportunities and respect allows the employee to be more productive, as they are free from judgment or 
discrimination by colleagues or superiors [18]. In Brazil, the guarantee of human rights and citizenship of the LGBT+ population is stated in four documents entitled "The Brazil Without Homophobia Program", the "Annals of the First National LGBT+ Conference", the "National Plan for the Promotion of Citizenship and LGBT+ Human Rights" and the "National Human Rights Program 3". However, although these events and documents foster dialogue between civil society and governments, there is still resistance in the implementation of plans and programs that would, in turn, have little normative force, generating uncertainty in the fight against homophobia and the promotion of LGBT+ citizenship [9].

The present qualitative research presents a case study on what was done by the municipal public power through the Special Coordination for Sexual Diversity (CEDS) in terms of guaranteeing human rights and the inclusion of the LGBT+ population of the city of Rio de Janeiro, capital of the State of Rio de Janeiro, in the South-eastern region of Brazil, from 2011 to 2016.

The objective is to identify the public policies and actions adopted and the impact perceived in the improvement of working conditions and quality of life for this population. It has been made clear that steps were taken towards valuing and including LGBT+ minorities through the creation of CEDS.

\section{Methodology}

The present work is a qualitative research and is thus classified due to the amplitude and multiplicity of interpretations that the theme allows through the understanding of phenomena occurring within specific contexts pertinent to the LGBT+ public. This creates the opportunity of personalizing the study under the prejudice-free gaze of these authors who created empathy for the reality faced by those studied [10-11].

Among the possible methodological variations, this article develops a case study on the "Rio Sem Preconceito" program, which trained transvestites and transsexual women for the labor market and municipal public servants for the correct treatment of different gender identities and sexual orientations, implemented by the Coordination of Social Diversity (CEDS) of the City Hall of the city of Rio de Janeiro, capital of the State of Rio, in the South-eastern Region of Brazil. For the investigation of what was done by the CEDS in terms of including LGBT+ minorities in the city of Rio de Janeiro, these researchers started with a review of theoretical literature, examining and comparing data on what has been done abroad and in Brazil in order to build a situated understanding of the problem and its connections with local cultures [11]. Seeking to meet the requirement of having multiple sources of evidence required by the case studies, data were collected from documentary evidence obtained at electronic websites of the city of Rio, printed articles and video recordings pertinent to published achievements, as well as an in- depth interview with the coordinator responsible for the implementation and management of the programs.

The in-depth interview was intended to understand "practices that exist in specific place, context and time" [11]. According to Gray [11], information-rich cases allow access to an amplified dimension of reality, particularly when compared to secondary data that dealt with objects and / or behaviors or characteristics similar to the current research.

In accordance to the most recent discussions about subjectivity and identity in human sciences research [12-1314], control was offered over the degree of identification that would be assumed in the research, and the interviewee said there was no problem for him to be identified, even being a public person. The qualitative interview was analyzed in contrast to the documental and bibliographic analysis done previously. A basic script was used in the informal interview, held on November 23, 2018, and burning questions were brought to the center of the debate, which took place in a face-toface meeting scheduled to deepen the understanding of the vision and opinion of the interviewee.

In order for the respondent to have no doubts about the ethical use of the data collected from the interview, nor any losses of any kind, he was presented with an informed consent form that was duly filled out and signed. After the primary and secondary data collections, the structural analysis was performed by following the cycle of five phases-compile, decompose, recompose, 
interpret and conclude [11]. The final structure of the work begins with this introduction, followed by the methodological aspects assumed in the research. Afterwards, we enter the literature review phase, which allowed for an overview of what has been done and discussed about the inclusion of excluded LGBT+ minorities in private organizations and in public institutions abroad, in Brazil and especially in the city of Rio de Janeiro.

Then, a case study based on analysis of primary and secondary data is presented and interpreted in the light of the qualitative research, allowing us to conclude on the results obtained with the actions implemented by the studied project with its target audience, where they fit into or innovate in relation to current practices in other similar experiences.

Hopefully this paper will be able to provide relevant information about the contribution that the city of Rio de Janeiro could give to society in terms of inclusion of diversity and respect for LGBT+ human rights, during the previous government, from 2011 to 2016 .

\section{Literature Review}

\section{Legitimizing LGBT + People as a Workforce at the Workplace}

The political and social activism of lesbian, gay, bisexual and transgender people has resulted in visibility and greater acceptance for the LGBT+ population, provoking a transformation in the political and legislative models aimed at equity and discrimination towards issues related to sexual orientation and gender identity in different parts of the world in the last few decades [15].

Despite the increasing diversity in the workforce, the element that perpetuates the demands for dif- ferment mechanisms that make sure these minority groups are heard, and changes are made in the legislation, organizational culture and social climate, is how common it still is for LGBT+ individuals to suffer discrimination, harassment and exclusion in professional environments [15].

Reduced satisfaction, hesitancy, the need for care and protection over what to tell colleagues and superiors, LGBT+ people's reduced concentration and commitment to their jobs are the results of a hostile and negative organizational environment where homophobic experiences are present and the discourse of heteronormativity is repeatedly accepted [1-16]. On the other hand, Yang and Konrad [3] argue that a considerable number of qualitative studies showing positive results on diversity management efforts suggest that effective results have been achieved, from initiatives to diversity management practices among all workgroups.

The fact that the link between diversity management practices and diversity of human capital has been well documented indicates that organizations have been at least somewhat effective in implementing processes with substantive impact Many field research documents suggest associations between diversity management practices and positive work attitudes, which in turn suggests that these practices are often accepted as legitimate by organizational members [3].

Considering that the greater variety in knowledge and experience generated by diversity could benefit the organization by providing a larger set of choices for managing problems and opportunities, organizations should allow employees to bring their entire 'selves' to work. In a positive or gay-friendly environment, LGBT+ people feel happier at work, which facilitates greater openness and leads to the enhancement of job satisfaction, productivity and effectiveness [1].

According to Colgan et al [1], the impact of working in a positive or gay-friendly environment is that LGBT+ people perform better at work. Happiness and openness, freedom to speak, greater confidence, feeling supported, enhancing enjoyment of job, feeling proud and loyal to organization are some of the impacts perceived in a positive environment, of which the result would be a super-or set of products and work processes.

\section{LGBT+ Human Rights in Brazil: what has been done at work and Society}

According to Theodorakopoulos and Budhwar [17], current literature shows that the agenda of diversity and inclusion in the workplace has gained international status among Human Resource managers and organizational leaders, not only in developed countries but also in emerging economies. For Irigaray [18], discussing the relationship 
between sexuality and the work environment is not only an organizational issue, but it is also a matter of public order, as it identifies the behavior of the actors involved, constructs expectations, defines positions and positions and includes access to certain privileges. DiMaggio and Powell [19] already stressed out the need to find ways to encourage diversification rather than maintenance of homogenization in organizations.

For them, pluralism adds value to deliberations in public policies. And this understanding has started to become a fact in Brazil too. In 2013, the Office of the United Nations High Commissioner for Human Rights (OHCHR) launched the "Free and equal births: sexual orientation and gender identity in international human rights law" in Brazil, available in Portuguese for download from the institution's website.

In it, one reads about the five obligations of the State, which are "to protect against homophobic violence, to prevent torture, to decriminalize homosexuality, to prohibit discrimination and to de- fend civil liberties." "Born Free and Equal" addresses the need to ensure protection for people who are victims of homophobic and transphobic violence, to prevent torture and cruel, inhuman and degrading treatment of LGBT+ people, to repeal laws criminalizing homosexuality.

To enable the prohibition of discrimination based on sexual orientation and gender identity and to protect the freedoms of expression, association and peaceful assembly for intersex and LGBT+ people. Dated back to December 2014, the 8th Forum of Companies and LGBT+ Rights had 14 companies formalizing their engagement in promoting human rights to LGBT+ people, in Brazil. In the occasion, such companies signed the commitment of "improving management practices in companies and influencing the corporate and social environment for adopting practices that respect LGBT+ human rights". It is one more step towards expanding the adoption of internal policies which encompasses people of different sexual orientations.

The Forum of Companies and LGBT+ Rights to fight homo lesbotransphobia and their negative effects on business, people and society, as well as to improve corporate management practices for adding value to their brands. Influencing the corporate environment and society through the adoption of practices that respect LGBT+ human rights is its other objective [20].

In order to do so, it has published a booklet titled "Business Commitment to LBGT Human Rights", avail- able at http.//www3.ethos.org.br/cedoc/businesscommitment-to-LGBT+human-

rights/\#.VLVU8kYGDp. In it, there are the "10 Commitments for Promoting LGBT+ Rights" which express the work agenda and the role the companies should adopt. These are shown on Table 1 below:

Table 1: 10 Commitments for Promoting LGBT+ Rights Source: Ethos, 2014. Adapted by the authors 10 Commitments for Promoting Lgbt+ Rights

\begin{tabular}{|l|}
\hline - Commit -CEO and executives - to respecting and promoting LGBT+ rights; \\
\hline - Promote equal opportunities and fair treatment to LGBT+ people; \\
\hline - Promote a respectful, safe and healthy environment for LGBT+ people; \\
\hline - Sensitize to and educate on LGBT+ rights; \\
\hline - Encourage and support the creation of LGBT+ affinity groups; \\
\hline - Promote respect for LGBT+ rights in communication and marketing; \\
\hline -Promote respect for LGBT+ rights in planning products, services and customer service; \\
\hline - Promote professional development actions for people of the LGBT+ segment; \\
\hline - Promote economic and social development of LGBT+ people in the value chain; \\
\hline - Promote and support actions aimed at LGBT+ rights in the community. \\
\hline
\end{tabular}

Another initiative implemented in the national scope was the publication of the booklet "Building equal opportunities in the world of work: combating homolesbotransphobia". Created for promoting the human rights of LGBT+ people in the world of work, this booklet was developed in partner- ship with UNAIDS and UNDP and is available on the website http.//www.pnud.org.br/arquivos/ MANUAL_ completo_ Direitos Humanos LGBT + \% 20 sem\% 20 marcas \% 20 de \%20impressao.pdf. Brazilian companies are starting to understand that to achieve their business 
success it is necessary to attract, retain and develop all employees, creating a diverse workforce where people can be brought together from all backgrounds, producing a more dynamic and cohesive team and more innovative goods and services. Brazilians are starting to understand that, not only abroad, diversity really means business.

\section{Rio: an Admittedly Gay-Friendly City}

Capital of the State of Rio de Janeiro, in the South-eastern region of Brazil, Rio de Janeiro ranks 45th among the 5,565 Brazilian municipalities according to the Municipal Human Development Index (IDHM). Among its 6.5 million inhabitants, $70.13 \%$ are aged between 15 and 64 years. Considering the adult population aged 25 years or above, $32.4 \%$ have completed High School and / or are in Universities and $21.3 \%$ have completed their Higher education.

The evolution of income in- equality in the city is described by the Gini Index, which increased from 0.60 in 1991 to 0.61 in 2000 and to 0.62 in 2010. Due to its tourist vocation for its location and geography, the city's city council, through the Special Coordination of Sexual Diversity (CEDS), launched the "Rio sem Preconceito" program in 2011 with the objective of training transvestites and transsexual women for the labor market and civil servants for the correct treatment of different gender identities and sexual orientations. Data published by the LGBT+ Chamber of Commerce and Tourism of Brazil indicate that $70 \%$ apprise Rio as a gay-friendly city in a survey conducted by Fundação Cesgranrio with 700 international LGBT+ tourists, between January 2 and 12, 2017.

The objective of the research was to identify the profile of tourists and from it create specific policies to improve the service, as this category of tourist spends two to three times more than a heterosexual tourist as for the negative points, $35 \%$ of foreign tourists pointed out the lack of information in the segment and $24 \%$ complained about security. Other data are described in Figure 2 below:

\begin{tabular}{|c|c|}
\hline Profile of the Lgbt+ Tourist & o during High Season \\
\hline Gender & $75 \%$ Men \\
\hline & $25 \%$ Women \\
\hline & 70\% Higher education \\
\hline Education level & $20 \%$ Basic education \\
\hline & 10\% Elementary level \\
\hline & $55 \%$ Europe \\
\hline & North America \\
\hline & South America \\
\hline & $5 \%$ Others \\
\hline & $80 \%$ by Air \\
\hline Form of Transportation Used & $15 \%$ by Sea \\
\hline & $5 \%$ Land \\
\hline & $65 \%$ Hotel \\
\hline & $25 \%$ Airbnb \\
\hline Accommodation & $8 \%$ Friends' \\
\hline & $2 \%$ Holiday apartment \\
\hline & $35 \%$ 1-3 days \\
\hline Average Time of Stay & $60 \% 4-7$ days \\
\hline & $5 \%$ More than 8 days \\
\hline & $30 \%$ 90-150 USD \\
\hline Average Spending Per Day & $45 \% 160-300$ USD \\
\hline & $25 \%$ More than 300 USD \\
\hline & $30 \% 18-27$ years \\
\hline & $44 \% 28-45$ years \\
\hline Age & $20 \% 46-65$ years \\
\hline & $6 \%$ over 65 years \\
\hline
\end{tabular}




\begin{tabular}{|c|c|}
\hline & $76 \%$ own their own \\
\hline \multirow[t]{2}{*}{ Travel Organization } & $24 \%$ Travel Agency \\
\hline & $70 \%$ Say the city is gay friendly \\
\hline \multirow[t]{4}{*}{ Rio as a LGBT+ Destination } & $20 \%$ Say the city is not gay friendly \\
\hline & 10\% Say they have no opinion \\
\hline & $30 \%$ Population receptivity \\
\hline & $25 \%$ Gastronomy \\
\hline \multirow[t]{6}{*}{ Main Positive Points of Rio } & 20\% Shopping Malls \\
\hline & $15 \%$ Tourist information spots \\
\hline & 10\% Cultural Diversity \\
\hline & $35 \%$ Lack of information for the segment \\
\hline & $24 \%$ Safety \\
\hline & 17\% Homeless population \\
\hline \multirow[t]{3}{*}{ Main Negative Points of Rio } & $10 \%$ urban cleanliness \\
\hline & $8 \%$ Taxis \\
\hline & 6\% Tourist information \\
\hline
\end{tabular}

Profile of LGBT+ Tourists who visit Rio during high season

Source: LGBT+ Chamber of Commerce and Tourism of Brazil, adapted by the authors

\section{Case Study}

The present case study investigated what was done by the municipal public power, through the Special Coordination of Sexual Diversity (CEDS), regarding the guarantee of human rights and inclusion of the LGBT+ population in the city of Rio de Janeiro, capital of the State of Rio de Janeiro, in the South-eastern region of Brazil, from 2011 to 2016. Simultaneously with the collection of secondary data, an interview was held with the CEDS' manager, who assumed the Special Coordination of Sexual Diversity (CEDS) on February 2, 2011, with the status of Municipal Secretary, who will be called $\mathrm{Mr}$ $\mathrm{CT}$, from now on.

The interviewee was offered control over his identification in the research, and he agreed to be identified by name, as he is a public figure. The informed consent form suggested by Gray [11] was duly completed and signed during the meeting held in a public place on November 23, 2018.

By feeling comfortable for being out, employees become more productive, and that is why organizational leaders should keep on helping their followers appreciate the value of individual differences by using their high status to seek out opportunities to support and encourage followers to apply for their individual differences to improve work processes [17].

Thinking accordingly, $\mathrm{Mr} \mathrm{CT}$ began the interview, which lasted approximately two hours, reporting that upon assuming the
CEDS he was immediately concerned with the Carnival celebrations in Rio, an event that attracts thousands of domestic and foreign tourists to the city. Until then, the city had never promoted an awareness campaign on the prevention of sexually transmitted diseases. Likewise, there was no concern to offer specific training to the municipal agents involved with Tourism for the better service and receptivity of the LGBT+ public. Mr CT says that because he was gay and a public person, a status which arose from his profession.

He was a militant HIV activist before engaging in LGBT+ human rights activism. Due to his preoccupation with the increase of infection levels in the periods of revelry, especially during Carnival, as manager of the CEDS, he implemented two campaigns for testing (the means to verify the serology and avoid the infection, interrupting the chain of transmission between individuals) and two annual prevention campaigns, leading Rio de Janeiro to be the city that conducts the most HIV tests in the country.

When the CEDS signed the 90-90-90 Agreement, the Joint United Nations Program on HIV / AIDS (UNAIDS), whose goal was that by 2020 , $90 \%$ of people must know their soro status, $90 \%$ of these must be undergoing treatment and $90 \%$ of those in treatment must reach the undetectable viral load, the city of Rio de Janeiro had already reached the goal of the first stage, since prevention work had already been done. 
For the first municipal information campaign on prevention, titled "Rio - Carnival without Prejudice", the Secretary invited ordinary friends and famous artists to talk about the prejudice suffered by blacks, women and the LGBT+ community.

The word 'homophobia', introduced in national (Brazil without Homophobia) and state (Rio without Homophobia) campaigns did not cover all minorities, and Mr CT chose to use the word 'prejudice', broadening the message about respect and civil rights of all the minorities. Considering the partnership established with the Mayor, the Secretary emphasized that this and all other programs implemented in his administration were only possible due to the absolute adherence and identification of the municipal leader with the proposals of the Coordination. In Mr CT's words, the Mayor "had this good thing - he was a guy who would see things happening and would make things happen.

He was with us! " CEDS/Rio broke national news when, through the personal friendship between $\mathrm{Mr} \mathrm{CT}$ and the director of an entertainment program broadcast on national network by the broadcaster with the largest market share in the country, he was able to make the show's participants wear the T-shirts of the campaign "Rio: Carnival without Prejudice."

T-shirts featuring the theme of the campaign were worn and aired for three consecutive days during the Carnival period in 2011. The repercussion of the campaign was considered a success and the Coordination gained political strength and space in social media, printed and televised.

The "Rio sem Preconceito" program was launched in May of the same year as an "umbrella" for other programs, each linked to other Municipal Departments, according to their pertinence. The CEDS, located within the Guanabara Palace, headquarters of the State Government, was responsible for the defense of LGBT+ Civil Rights through the care, reception and referral of complaints made by citizens in vulnerable conditions.

The calls were accordingly taken, that is, gays would talk to gays, lesbians to lesbians, and transsexuals to transsexuals. This measure contributed to the perception of belongingness and solidarity of the State towards its citizens.
The Ministry of Health was responsible for HIV prevention campaigns. The "Rio Escola sem Pre- conceito" ("Schools without Prejudice") program coincided with the approval of the Homophobic Bullying Act by CEDS. In Culture, two Cultural public notices, each of which allocated $\mathrm{R} \$ 1$ milli- on for the financing of theatrical pieces or audiovisual programs that presented the LGBT+ theme, especially those focused on transsexualism and combating transphobia.

In the words of the interviewee, "there is a spectrum of prejudice towards the LGBT+ public, and transsexual people are the ones who suffer the most." One of the explicit conditions for prioritization in the funds from the tender was for the project to employ transsexual people. Mr CT reports that of all projects, the annual campaign against LGBT+-phobia was the one that had the most positive impact on the population of Rio de Janeiro.

The "Rio without Preconceito" campaign had 8 million viewers on Face book, and although difficult to measure, in her words, "it put on the agenda the fact that Brazil is the country that kills the most transsexuals and homosexuals in the whole world" according to Transgender Europe (TGEU). The CEDS complaint in the video created controversy and brought threats to the Secretary who, as he reiterated, had the unconditional support and protection of the mayor.

As CEDS coordinator, MrCT signed eight decrees. The one he is most proud of is Decree 35,816, of June 28, 2012. Through a CEDS / Rio initiative, the Unified Health System (SUS) started to register cases of homophobia and transphobia in the country, aiming to subsidize future actions of public policies to prevent and combat violence suffered by lesbian, gay, bisexual and transgender.

In completing the protocol of the Report of the National Health Information System (SINAN) of the Ministry of Health, the first professionals of the public or private municipal health network that care to people affected by an aggravated or heinous crime to be obliged to declare in detail the fact and place of occurrence, allowing such victims to be protected by sanctions that can be applied to establishments or individuals that do not respect or somehow violate the rights of the LGBT+ population. 
The Decree began to be used nationally and Rio de Janeiro went on to rank first place among Brazilian cities that protect the rights of LGBT+ citizens. With the defeat of the candidate of the government to the city hall of Rio in the elections of 2016, the Secretaries had their managers exonerated of their positions, team members were fired and the projects were either interrupted or altered.

The current public management in the municipal, state and federal spheres is carried out by politicians, whose speech is declared "heteronormative", which MrCT admits has increased his own pessimism. The CEDS / Rio coordinator, who has been removed from the CEDS and is determined not to run for public office, concludes the interview by expressing concern about the continuity of actions that ensure respect and civil rights for lesbian, gay, bisexual and transgender people.

\section{Results}

The objective of identifying the public policies and actions adopted as well as the perceived impacts on the improvement of the working and living conditions of this population has been achieved, as the case study demonstrates the steps taken towards valuing and including LGBT+ minorities in the management of CEDS / Rio, carried out in the period from 2011 to 2016. In the words of $\mathrm{MrCT}$, the LGBT+ tourist is a public that

\section{References}

1. Colgan F et al (2007) "Equality and diversity policies and practices at work: lesbian, gay and bisexual workers", Equal Opportunities International, 26(6):590609.

2. Dahling JJ et al (2016) "A stake in the fight: When do heterosexual employees resist organizational policies that deny marriage equality to LGB peers?" In Organizational Behavior and Human Decision Processes, 132:1-15.

3. Yang Y, Konrad AM (2011) "Understanding diversity management practices: Implications of institutional theory and resource-based theory", Group \& Organization Management, 36(1):6-38.

4. Barbieri UF (2014) Gestão de Pessoas nas organizações: An evolução do ser humano na vida e na carreira. Atlas. São Paulo.

5. Marras JP (2011) Administração de "defines its destiny in terms of destinies that assure their rights".

A series of laws was created in the period from 2011 to 2016 that have re- sulted in the exponential increase of gay tourism. Far from coming just for sex tourism, the interviewee ensures that LGBT+ people come to visit museums, restaurants and stroll through tourist spots, paying a cost of living three times higher than the city of Mykonos, for example.

In his opinion, the Rio lifestyle where people walk around in shorts and bermudas, the location of the beaches in the urban perimeter and respect for diversity and civil rights legally assured to lesbian, gay, bisexual and transgender people, accredit the city as a gay friendly destination. More than just attracting the LGBT+ community, gay tourism provides revenue that the city and its representatives cannot ignore.

Literally, diversity does mean business. As a proposal for future work, these authors suggest that new studies are done to verify the evolution or involution of CEDS/Rio's actions, which projects have had continuity, the impact obtained by those that were altered and the repercussion generated by those that were interrupted by determination of the democratically elected mayor and his staff, whose term began on January 1st, 2017 and will last until December 31, 2020 [21-34].

Recursos Humanos: do operacional ao estratégico, $14^{\mathrm{a}}$ ed., São Paulo, Saraiva.

6. Moraes J, Oliveira SR (2011) Gestão de Pessoas, Sesi: Uff, Rio de Janeiro.

7. Rumens N (2011) "Minority support: Friendship and the development of gay and lesbian managerial careers and identities", Equality, Diversity and Inclusion: An International Journal, 30(6):444-462.

8. Fullerton M (2013) "Diversity and inclusion -LGBT+ inclusion means business", Strategic HR Review, 12(3):121125.

http.//doi.org/10.1108/1475439131134462 (accessed 28 May 2017).

9. Mello L (2012) Políticas Públicas de segurança para a população LGBT+ no Brasil. Revista Estudos Feministas, 22 (1):297-320, Jan/Apr. 2014. 
10. Gray DE (2012) Pesquisa no Mundo Real, $2^{\mathrm{a}}$ ed. Penso, Porto Alegre.

11. Yin R (2016) Pesquisa Qualitativa do Início ao Fim. Porto Alegre: Penso.

12. Araújo CM et al (2017) O sujeito na pesquisa qualitativa: desafios da investigação dos processos de desenvolvimento, Psicologia: Teoria e Pesquisa, 33, Brasília-DF, DOI http.//dx.doi.org/10.1590/0102;3772e33316.

13. Barthes R (1976) Introdução à análise estrutural da narrativa. In R. Barthes, Análise estrutural da narrativa: Pesquisas semiológicas, Petrópolis: Vozes, (19-60).

14. Denzin NK, Lincoln YS (2006) O Planejamento da Pesquisa Qualitativa: Teoriase Abordagens, Artmed, Porto Alegre.

15. Colgan F, Mc Kearney A (2012) "Visibility and voice in organizations: Lesbian, gay, bisexual and transgendered employee networks", Equality, Diversity and Inclusion: An International Journal, 31(4):359-378.

16. Almeida et al (2018) 'People Management and the Commitment of Brazilian Organizations towards Diversity: The Challenges of Implementing Theory in Practice', Asian Journal of Business \& Management Sciences,07(01):1-15

17. Theodorakopoulos N, Pawan B (2015) "Diversity and inclusion in different work settings: emerging patterns, challenges, and research agenda". In Human Resource Management, 54(2):177-197.

18. Irigaray HAR et al (2010) Humor e Discriminação por Orientação Sexual no Ambiente Organizacional (1). RAC, Curitiba 14(5-7):890-906.

19. Di Maggio P, Powell WW (1983) 'the iron cage revisited: Collective rationality and institutional isomorphism in organizational fields', American Sociological Review, 48(2):147-160.

20. Forum (2013) in https://www.revistaforum.com.br/osentend idos/2017/02/13/tufvesson-

fazbalancoperiodo-como-coordenador-daceds/ (accessed on 19 November 2018).

21. ACNUDH (2013) Alto Comissariado das Nações Unidas para os Direitos Humanos. In: http.//acnudh.org/pt-br/dia-dos-direitos- humanos-2013-acnudh-organiza-painelsobreorgaos-de-tra- tados (accessed 06 June 2017).

22. ACNUDH (2013) Cartilha Nascidos Livres e Iguais. In: http.//acnudh.org/wpcontent/ uploads/2013/03/Nascidos-Livres-e-IguaisBaixa-Resolu\%C3\%A7\%C3\%A3o.pdf.

23. Atlas Brasil (2013) in http.//atlasbrasil.org.br/2013/pt/perfil_m/ri o-de-janeiro_rj (accessed 20 November 2018).

24. Câmara LGBT + (2009) in http.//www.camaraLGBT+.com.br/LGBT+70-aprovam-o-rio-comoci- dade-gayfriendly/ (accessed 25 November 2018).

25. Clark D (2012) Come out of the closet at work. Whether you're gay or not. In Harvard Business Review. In: http.//hbr.org/2012/07/come-out-of-thecloset-at-work (accessed 28 May 2017).

26. Egan PJ et al (2008) "Gay Rights." In Public Opinion and Constitutional Controversy, eds. Nathaniel Persily, Jack Citrin and Patrick J. Egan. Oxford University Press.

27. Egan PJ (2009) "Reducing LGBT+ Inequality in the Age of Obama". In National Equality March in Washington, DC, on October 11. http.//politics.as.nyu.edu/docs/IO/4819/ega n. pathways.pdf (accessed 28 May 2017).

28. Entre Nós (2010) in https://blogentrenos.wordpress.com/tag/sec retaria-de-direitoshumanos-dapresidencia-da-republica/ (accessed 25 November 2018).

29. Instituto Ethos (2014) In http.//www3.ethos.org.br/cedoc/catorzeempresas-assinamcarta- de-compromissocom-os-direitos-LGBT+/\#.WStH2RtViko (accessed 2 June 2017)

30. Mello L (2012) Por onde andam as Políticas Públicas para a População LGBT+ no Brasil. Revista Sociedade e Estado- 27-2 - May/Aug.

31. Mello L. et al (2012) Questões LGBT+ em debate: sobre desafios e conquistas. Soc. E Cult., Goiânia, v. 15, n. 1, p. 151-161, Jan/Jun 2012, DOI: 10.5216/sec.v.15i1. 20680.

32. Ministério da Saúde (2016) In http.//www.aids.gov.br/pt-br/noticias/novo- 
relatorio-dounaids-sobre-o-90-90-90-cita-obrasil-como-exemplo-de-que-meta-pode-ser (accessed 25 November 2018)

33. Lucon $\mathrm{N}$

https://nlucon.com/2016/11/15/novorelatorio-da-tgeu-reafirma-quebrasil-e-opais-que-mais-mata-pessoas-trans-nomundo/ (accessed 25 November 2018)

34. UNAIDS (2015)

http.//www.pnud.org.br/arquivos/

in:
Manual_ comple to_Direitos Hum anos LGBT + \% 20 sem \% 20 marcas \% 20de\%20impressao.pdf .United Nations Global Impacts. In https://www.unglobalcompact.org/docs/issu es_doc/human_rights/Webinars/Business_ LGB T_10Feb15.pdf (accessed on 19 November 2018).

In 